\title{
PENGUKURAN BEBAN KERJA DENGAN METODE FISIOLOGI (STUDI KASUS PADA “X” FITNESS CENTER AMBON)
}

\author{
Novita Irma Diana Magrib \\ Program Studi Teknik Industri \\ Universitas Darussalam Ambon \\ Email : maynov8@yahoo.com
}

\begin{abstract}
Services provided by the " $X$ " fitness center fitness facility with a variety of tools already available, the $S$ "X" fitness center, most customers are men, where most of the activities carried out are activities of lifting barbells of various sizes. From this it will be calculated the amount of energy consumption based on heart rate and recommend the lifting load limit corresponding to anthropometrics Indonesian workers. Based on the calculation of loading equation then the average energy required for lifting the load $12 \mathrm{Kg}, 16 \mathrm{~kg}$, and 20 Kg were 3-6 kilocalories / minute. Thus removal of the load on the " $X$ " Fitness Center with a size of $12 \mathrm{~kg}, 16 \mathrm{~kg}$ and $20 \mathrm{~kg}$ was allowed for the appointment, because the load with so many sizes still categorized in mild and moderate workloads
\end{abstract}

Keywords: Anthropometry, ergonomic, physiology

\section{PENDAHULUAN}

Penggunaan tenaga manusia sangat dominan terutama dalam pekerjaan angkat angkut beban. Karena kerja manusia bersifat mental dan fisik yang masing-masing memiliki intensitas yang berbeda. Tingkat intensitas yang terlampau tinggi memungkinkan pemakaian energi yang berlebihan, sebaliknya intensitas yang terlalu rendah menimbulkan rasa bosan dan jenuh. Usaha-usaha ergonomis diarahkan pada pencapaian tingkat intensitas optimum yang ada diantara kedua batas ekstrim tadi, dimana tingkat optimum ini berbeda untuk tiap individunya.

Berdasarkan gambaran diatas maka perkembagan dunia kefaalan dengan pengukuran denyut jantung sangat penting diketahui bukan saja oleh kalangan kesehatan tetapi juga oleh kalangan industri, baik industri rumah tangga, industri sekunder maupun industri tersier. "X" fitness center merupakan salah satu industri yang bergerak dalam bidang pelayanan jasa atau sering disebut sebagai industri tersier. Pelayanan jasa yang diberikan oleh "X" fitness center berupa fasilitas kebugaran dengan berbagai alat yang telah tersedia, pada "X" fitness center ini sebagian besar konsumen adalah pria, dimana sebagian besar aktivitas yang dilakukan adalah kegiatan mengangkat barbel dengan berbagai ukuran.

\section{TINJAUAN PUSTAKA}

\section{Pendekatan fisiologi}

Untuk menentukan Kapasitas angkat beban maksimum secara fisiologis kita harus mengetahui konsumsi energi yang dibutuhkan pada saat bekerja.

\section{Konsumsi energi}

Pengukuran konsumsi energi dapat dilakukan dengan 2 cara yaitu cara langsung dengan mengetahui konsumsi oksigen serta cara tidak langsung dengan mengetahui kecepatan denyut jantung.

1. Konsumsi Energi berdasarkan Konsumsi Oksigen

Konsumsi oksigen merupakan faktor dari proses metabolisme yang berhubungan langsung dengan konsumsi energi. Konsumsi oksigen akan terus berlangsung walaupun seseorang tidak melakukan pekerjaan sekalipun. Untuk itu dalam perhitungan konsumsi energi dibagi dalam beberapa keadaan yaitu konsumsi energi pada saat 
istirahat (metabolisme basal) dan pada saat bekerja.

A. Konsumsi energi pada saat istirahat (metabolisme basal)

Metabolisme basal atau Basal metabolic Rate (BMR) merupakan jumlah minimal energi yang dibutuhkan untuk melakukan berbagai proses vital ketika tubuh dalam keadaan beristirahat. BMR dipengaruhi oleh berbagai faktor diantaranya : luas permukaan tubuh, jenis kelamin, usia, keaktifan kelenjar penghasil hormon, dan massa tubuh tak berlemak (Arisman, 2004).

a. Luas permukaan tubuh

Pengaruh luas permukaan tubuh Jika dibandingkan dengan orang yang bertubuh gemuk pendek dan orang yang bertubuh kurus jangkung dengan berat badan sama, maka BMR orang yang bertubuh kurus jangkung lebih besar karena luas permukaan tubuhnya lebih besar dari orang yang bertubuh gemuk pendek.

b. Usia

Nilai BMR semasa pertumbuhan cukup besar karena aktifnya pembelahan sel. Setelah pertumbuhan usai, rata -rata setelah usia 25 tahun, BMR akan susut sebanyak $2-5 \%$ per dekade hingga mencapai usia 65 tahun.

c. Jenis Kelamin

BMR wanita 5-10 \% lebih rendah dari BMR laki-laki (tinggi dan berat badan sama) hal ini dipengaruhi oleh aktifitas hormon. Terutama pada wanita dewasa BMR berfluktuasi menurut siklus haid. Perbedaan antara titik terendah (1 minggu sebelum ovulasi) dan tertinggi (sebelum haid) diperkirakan sebesar $359 \mathrm{kcal} /$ hari. Keadaan ini tercipta karena pada saat praovulasi (kadar progesteron lebih tinggi) nilai BMR lebih rendah 6-5\% dibandingkan masa prahaid (estrogen lebih dominan). Menurut Grandjean (1986), BMR untuk laki - laki dengan berat badan $70 \mathrm{~kg}$ sebesar $1700 \mathrm{kcal} / 24$ jam, sedangkan untuk wanita dengan berat badan $60 \mathrm{~kg}$ BMR nya sebesar $1400 \mathrm{~kg} / 24 \mathrm{jam}$.

Beberapa penelitian menunjukkan adanya variasi nilai BMR sebesar 1\%- 4\% terhadap dua atau lebih pengukuran BMR pada subjek yang sama disaat yang berbeda.

B. Konsumsi energi kerja

Konsumsi energi pada saat pekerjaan fisik dimulai dan akan bertambah atau berkurang sesuai dengan beban kerja yang diberikan. Jadi konsumsi energi untuk melakukan kerja tertentu adalah selisih antara pengeluaran energi setelah kerja dengan pengeluaran energi pada saat istirahat.

\section{Konsumsi Energi berdasarkan Denyut Jantung}

Dalam kondisi normal atau sedang beristirahat, laju detak jantung manusia berkisar diantara 70 bit/menit. Ketika sedang dalam kondisi bekerja, rata-rata laju detak jantung mengalami kenaikan menjadi sekitar 110 bit/menit.

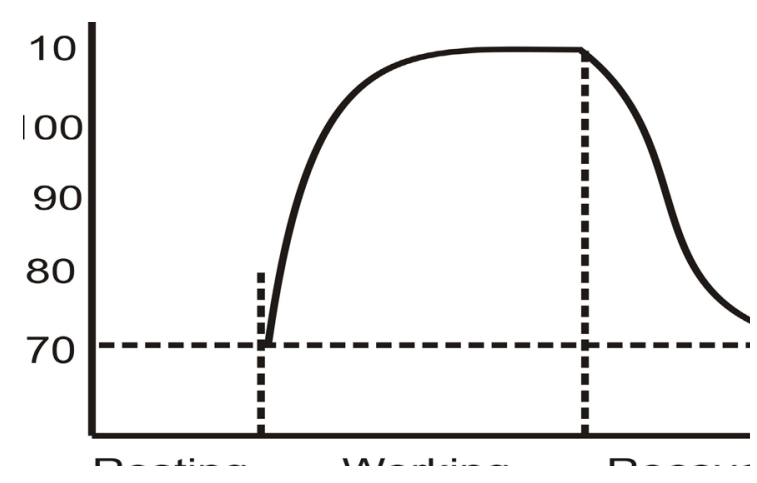

Gambar Siklus denyut nadi (Grandjean, 1986)

Dari grafik diatas dapat diketahui bahwa seseorang dalam kedaan normal:

a. Waktu sebelum kerja (rest) kecepatan denyut jantung dalam keadaan konstan walaupun ada perubahan kecepatan denyutnya tetapi tidak terlalu jauh perbedaanya.

b. Waktu selama bekerja (work) kecepatan denyut jantung dalam keadaan naik. Semakin lama waktu kerja yang dilakukan maka makin banyak energi yang keluar sehingga kecepatan denyut jantung bertambah cepat.

c. Waktu pemulihan (recovery) kecepatan denyut jantung semakin menurun.

Kecepatan denyut jantung selain dapat diukur dengan menggunakan alat seperticardio tachometer dan pulse meter juga dapat diukur secara manual dengan meraba denyutan pada arteri radialis.

Perhitungan konsumsi energi dengan denyut jantung digunakan persamaan regresi untuk mengestimasi energi berdasarkan kecepatan denyut jantung (Asnaldi, 2009).

\section{Antropometri}

Antropometri Dan Aplikasinya Dalam 


\section{Perencangan fasilitas Kerja.}

Secara definitif antropometrik dapat dinyatakan sebagai satu studi yang berkaitan dengan pengukuran dimensi tubuh manusia. Manusia pada dasarnya akan memiliki bentuk, ukuran (tinggi, lebar, dsb) berat dan lain-lain yang berbeda satu dengan yang lainya. Antropometri secara luas akan digunakan sebagai pertimbangan ergonomis dalam proses perancangan (design) produk maupun sistem kerja yang akan memerlukan interaksi manusia. Data antropometri yang berhasil diperoleh akan diaplikasikan secara luas antara lain dalam hal:

1. Perancangan areal kerja (work station, interior mobil, dll)

2. Perancangan peralatan kerja seperti mesin, equipment, perkakas (tools) dan sebagainya.

3. Perancangan produk-produk konsumtif seperti pakaian, kursi/meja, computer, dll.

4. Perancangan lingkungan kerja fisik.

Dengan demikian dapat disimpulkan bahwa data antropometri akan menentukan bentuk, ukuran dan dimensi yang tepat yang berkaitan denagn produk yang dirancang dan manusia yang akan mengoperasikan/menggunakan produk tersebut. Dalam kaitan ini maka perancangan produk harus mampu mengakomodasikan dimensi tubuh dari populasi terbesar yang akan menggunakan produk hasil rancangannya tersebut.

\section{Analisis Statistik}

Analisis statistik berdasarkan persyaratan distribusi datanya secara umum dapat dibedakan menjadi dua kelompok, yaitu: Analisis Statistik Parametrik : data yang harus memenuhi persyaratan distribusi tertentu. Analisis Statistik Non Parametrik : tidak memerlukan persyaratan distribusi data tertentu.

Statistik parametrik adalah prosedur analisis statistik yang memerlukan pemenuhan atas persyaratan asumsi-asumsi dasar distribusi data pada variabel yang digunakan dalam analisis.

Statistik parametrik memerlukan beberapa pengujian pendahuluan sebagai prasyarat analisis. Hal tersebut terjadi karena pengujian statistik dalam beberapa jenis analisis memang lazimnya disyaratkan untuk memenuhi asumsi-asumsi tertentu sebelum analisis dilakukan. Persyaratan distribusi data merupakan unsur yang sangat penting dalam menetukan pemilihan statistik alat uji kerena beberapa analisis statistik memang memiliki persyaratan data tertentu.

\section{Uji Linearitas}

Sebelum analisis regresi dilaksanakan, terlebih dahulu dilakukan pengujian linearitas yaitu uji normalitas data dan bebas dari asumsi klasik yang meliputi multikolinearitas, autokorelasi, dan heteroskedastisitas. Menurut Surjadi (1990) menjelaskan bahwa uji distribusi normal adalah uji untuk mengukur apakah data kita memiliki distribusi normal sehingga dapat dipakai dalam statistik parametrik.

Berdasarkan definisi diatas, tujuan dari dilakukannya uji normalitas tentu saja untuk mengetahui apakah suatu variabel normal atau tidak. Normal disini dalam arti mempunyai distribusi data yang normal.

\section{Analisis Regresi}

Analisis regresi merupakan salah satu analisis yang bertujuan untuk mengetahui pengaruh suatu variabel terhadap variabel lain. Dalam analisis regresi, variabel yang mempengaruhi disebut Independent Variable (variabel bebas) dan variabel yang dipengaruhi disebut Dependent Variable (variabel terikat). Jika dalam persamaan regresi hanya terdapat satu variabel bebas dan satu variabel terikat, maka disebut sebagai persamaan regresi sederhana, sedangkan jika variabel bebasnya lebih dari satu, maka disebut sebagai persamaan regresi berganda.

Analisis Regresi Sederhana: digunakan untuk mengetahui pengaruh dari variabel bebas terhadap variabel terikat atau dengan kata lain untuk mengetahui seberapa jauh perubahan variabel bebas dalam mempengaruhi variabel terikat. Dalam analisis regresi sederhana, pengaruh satu variabel bebas terhadap variabel terikat dapat dibuat persamaan sebagai berikut:

$$
\mathrm{Y}=\mathrm{a}+\mathrm{b} \mathrm{X}
$$

Keterangan :

Y : Variabel terikat (Dependent Variable).

$\mathrm{X}$ : Variabel bebas (Independent Variable).

a : Konstanta; dan b : Koefisien Regresi.

Untuk mencari persamaan garis regresi dapat digunakan berbagai pendekatan (rumus), sehingga nilai konstanta (a) dan nilai koefisien regresi (b) dapat dicari dengan metode sebagai berikut:

$$
\mathrm{a}=\left[\left(\sum \mathrm{Y} \times \sum \mathrm{X} 2\right)-\left(\sum \mathrm{X} \times \sum \mathrm{XY}\right)\right] /\left[\left(\mathrm{N} \times \sum \mathrm{X} 2\right)\right.
$$


$\left.-\left(\sum \mathrm{X}\right) 2\right]$ atau a $=(\Sigma \mathrm{Y} / \mathrm{N})-\mathrm{b}(\Sigma \mathrm{X} / \mathrm{N})$

$$
\mathrm{b}=[\mathrm{N}(\Sigma \mathrm{XY})-(\Sigma \mathrm{X} . \Sigma \mathrm{Y})] /[(\mathrm{N} . \Sigma \mathrm{X} 2)-(\Sigma \mathrm{X}) 2] .
$$

Analisis regresi berganda didefinisikan sebagai pengaruh antara dua variabel, dimana terdiri dari 2 atau lebih variabel independent (bebas) dan 1 variabel dependent (terikat).

Rumus persamaan regresi berganda :

$$
\mathrm{Y}=\mathrm{a}+\mathrm{b} 1 \mathrm{X} 1+\mathrm{b} 2 \mathrm{X} 2+\ldots \ldots . .+\mathrm{bnXn}
$$

\section{METODOLOGI PENELITIAN}

\section{Prosedur Penelitian}

Penelitian dimulai dengan menentukan frekuensi pengangkatan, dan berat beban. Berdasarkan hasil penelitian maka diambil sampel beban sebesar 12 $\mathrm{kg}, 16 \mathrm{~kg}$ dan $20 \mathrm{~kg}$ dengan frekuensi pengangkatan 5 angkatan/menit. Pengangkatan dilakukan selama 5-7 menit dengan waktu istirahat antara perlakuan selama 10-20 menit sampai denyut nadi pekerja sesuai atau mendekati denyut nadi awal.

Setelah ditentukan berat beban dan frekuensi pengangkatan, dilakukan pengukuran denyut nadi sebelum dan sesudah perlakuan. Pengukuran denyut nadi dilakukan secara manual selama 30 detik dengan merasakan denyutan pada ateri radialis.

\section{Langkah-langkah Penentuan}

a. Perhitungan konsumsi energi hasil estimasi denyut jantung

Konsumsi energi diperoleh dengan cara mengsubtitusikan data denyut jantung sebelum bekerja dan sesudah bekerja.

b. Perhitungan total konsumsi energi

Konsumsi energi diperoleh dengan cara mengsubtitusikan hasil perhitungan.

c. Uji normalitas data denyut jantung

Uji normalitas dilakukan untuk mengetahui apakah suatu variabel dianggap normal atau tidak.

d. Uji $t$ data denyut jantung

uji $t$ dilakukan untuk melihat apakah terdapat perbedaan antara denyut jantung sebelum dan sesudah bekerja.

e. Penentuan persamaan pembebanan

Persamaan pembebanan diperoleh dengan melakukan uji regresi terhadap variabel energi, umur, berat badan, dan tinggi badan.

\section{PEMBAHASAN}

\section{Perhitungan Konsumsi Energi Hasil Estimasi Denyut Jantung}

Dari hasil penelitian maka diperoleh data denyut jantung untuk 30 sampel yang terlihat pada tabel dibawah ini :

\begin{tabular}{|c|c|c|c|c|c|c|}
\hline \multirow[t]{6}{*}{ No } & \multirow{2}{*}{\multicolumn{2}{|c|}{$\begin{array}{c}\text { Frekuel } \\
\text { Beban } 12 \mathrm{Kg}\end{array}$}} & \multirow{2}{*}{\multicolumn{4}{|c|}{ Denyut Jantung 5 Angkatan/Menit }} \\
\hline & & & Beb & & & \\
\hline & Denyut & Denyut & Denyut & Denyut & Denyut & Denyut \\
\hline & Nadi & Nadi & Nadi & Nadi & Nadi & Nadi \\
\hline & Sebelum & Sesudah & Sebelum & Sesudah & Sebelum & Sesudah \\
\hline & Bekerja & Bekerja & Bekerja & Bekerja & Bekerja & Bekerja \\
\hline & $\frac{80}{80}$ & 143 & $\frac{80}{80}$ & 156 & $\frac{80}{80}$ & 164 \\
\hline 3 & & & & 23 & & 140 \\
\hline 4 & 74 & 05 & 74 & 30 & 74 & 144 \\
\hline 5 & 88 & 22 & 88 & 35 & 88 & 146 \\
\hline 6 & 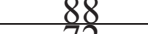 & 012 & $\left.\frac{88}{72} \cdot r \cdot r \cdot r \cdot r \cdot r \cdot r\right)$ & $\frac{27}{20}$ & 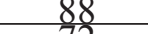 & $\frac{36}{12}$ \\
\hline & $\frac{12}{77}$ & $\frac{21}{03}$ & $\frac{12}{72}$ & $\frac{50}{25}$ & $\frac{12}{72}$ & $\frac{143}{128}$ \\
\hline 9 & 80 & 30 & 80 & 48 & 80 & $\frac{130}{156}$ \\
\hline 10 & 80 & & 80 & 22 & 80 & 30 \\
\hline 11 & 84 & 20 & 84 & $\frac{36}{57}$ & 84 & 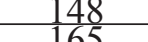 \\
\hline & & & & 44 & & \\
\hline 14 & 74 & 25 & 74 & 136 & 74 & 142 \\
\hline 15 & 74 & 135 & 74 & 156 & 74 & 162 \\
\hline 16 & 72 & 139 & 72 & 148 & 72 & 158 \\
\hline 17 & 72 & 110 & 72 & 137 & 72 & 150 \\
\hline 18 & 88 & 124 & 88 & 135 & 88 & 160 \\
\hline
\end{tabular}

Tabel Data Denyut Jantung 


\begin{tabular}{|l|l|l|l|l|l|l|}
\hline 19 & 88 & 128 & 88 & 132 & 88 & 148 \\
\hline 20 & 80 & 124 & 80 & 128 & 80 & 140 \\
\hline 21 & 80 & 121 & 80 & 130 & 80 & 150 \\
\hline 22 & 74 & 133 & 74 & 146 & 74 & 158 \\
\hline 23 & 72 & 115 & 72 & 123 & 72 & 132 \\
\hline 24 & 84 & 130 & 84 & 152 & 84 & 168 \\
\hline 25 & 82 & 125 & 82 & 149 & 82 & 164 \\
\hline 26 & 88 & 120 & 88 & 145 & 88 & 158 \\
\hline 27 & 84 & 125 & 84 & 142 & 84 & 152 \\
\hline 28 & 80 & 121 & 80 & 135 & 80 & 144 \\
\hline 29 & 82 & 120 & 82 & 130 & 82 & 152 \\
\hline 30 & 80 & 120 & 80 & 140 & 80 & 164 \\
\hline
\end{tabular}

Berdasarkan hasil perhitungan estimasi denyut jantung, maka konsumsi energi hasil estimasi denyut jantung sebelum bekerja dan sesudah

bekerja untuk beban $12 \mathrm{~kg}$, $16 \mathrm{Kg}$, dan $20 \mathrm{Kg}$ terlihat pada tabel di bawah ini:

Tabel Konsumsi Energi Hasil Estimasi Denyut Jantung

\begin{tabular}{|c|c|c|c|c|c|c|}
\hline \multirow[b]{6}{*}{$\mathrm{No}$} & \multicolumn{2}{|c|}{ Beban $12 \mathrm{~kg}$} & \multicolumn{2}{|c|}{ Beban $16 \mathrm{~kg}$} & \multicolumn{2}{|c|}{ Beban $20 \mathrm{~kg}$} \\
\hline & Energi & Energi & Energi & Energi & Energi & Energi \\
\hline & Sebelum & Sesudah & Sebelum & Sesudah & Sebelum & Sesudah \\
\hline & Bekerja & Bekerja & Bekerja & Bekerja & Bekerja & Bekerja \\
\hline & (kilokalori & (kilokalori & (kilokalori & (kilokalori & (kilokalori & (kilokalori \\
\hline & /menit) & /menit) & /menit) & /menit) & /menit) & /menit) \\
\hline & 2.99 & 8.18 & 2.99 & 9.71 & 2.99 & \\
\hline 2 & 2.99 & 7.84 & 2.99 & & 2.99 & \\
\hline 3 & 2.69 & 5.41 & 2.69 & 6.12 & 2.69 & \\
\hline 4 & 2.69 & 4.60 & 2.69 & 6.80 & 2.69 & \\
\hline 5 & 3.44 & 6.03 & 3.44 & 7.31 & 3.44 & \\
\hline 6 & 3.44 & & 3.44 & 6.50 & 3.44 & \\
\hline 7 & 2.60 & 5.94 & 2.60 & 6.80 & 2.60 & \\
\hline 8 & 2.60 & 4.45 & 2.60 & & 2.60 & \\
\hline 9 & 299 & 6.80 & 2.99 & 8.75 & 2.99 & 9 \\
\hline 10 & 2.99 & 5.58 & 2.99 & 6.03 & 2.99 & \\
\hline & 3.21 & & & 7.41 & 3.21 & \\
\hline & 3.21 & & .21 & 9.84 & 3.21 & 10.87 \\
\hline 3 & 3.21 & & 3.21 & 8.29 & 3.21 & 9.96 \\
\hline 4 & 2.69 & 6.31 & 2.69 & 741 & 2.69 & 8.06 \\
\hline 5 & 2.69 & & 2.69 & & 2.69 & 10.47 \\
\hline 6 & 2.60 & 7.73 & 2.60 & 8. & 2.60 & 9.96 \\
\hline 17 & 2.60 & 4.99 & 2.60 & & 2.60 & 8.98 \\
\hline 8 & 3.44 & 6.22 & 3.44 & & 3.44 & \\
\hline 19 & 3.44 & 6.60 & $\frac{3.44}{3.44}$ & 7.00 & $\frac{3.54}{3.44}$ & 8.75 \\
\hline 20 & 2.99 & 6.22 & 2.99 & 6.60 & 2.99 & \\
\hline & 2.99 & 5.94 & 2.99 & 6.80 & 2.99 & 8.98 \\
\hline 22 & 2.69 & 7.10 & 2.69 & & 2.69 & 9.96 \\
\hline & 2.60 & & 2.60 & 6.12 & 2.60 & 7.00 \\
\hline & & 6.80 & & 9.22 & 3.21 & \\
\hline 25 & 3.10 & 6.31 & 3.10 & 8.86 & 3.10 & 0.74 \\
\hline 26 & 3.44 & 5.85 & 3.44 & 8.40 & 3.44 & 9.96 \\
\hline 27 & 3.21 & 6.31 & & 8.06 & 21 & 922 \\
\hline 28 & 2.99 & 5.94 & 2.99 & 731 & 2.99 & 829 \\
\hline 29 & 3.10 & 5.85 & 3.10 & 6.80 & 3.10 & 922 \\
\hline 30 & 2.99 & 5.85 & 2.99 & 7.84 & 2.99 & 10.74 \\
\hline
\end{tabular}

\section{Konsumsi Energi}

Hasil konversi denyut jantung ke energi dapat dilihat pada tabel di bawah ini :

Tabel Total Konsumsi Energi

\begin{tabular}{|c|c|c|c|}
\hline & $\begin{array}{c}\text { Total Energi } \\
\text { Untuk Beban 12 } \\
\text { Kg (kilokalori/ } \\
\text { menit) }\end{array}$ & $\begin{array}{c}\text { Total Energi } \\
\text { Untuk Beban 16 } \\
\text { Kg (kilokalori/ } \\
\text { menit) }\end{array}$ & $\begin{array}{c}\text { Total Energi } \\
\text { Untuk Beban } \\
\text { 20Kg (kilokalori/ } \\
\text { menit) }\end{array}$ \\
\hline 1 & 5.18 & 6.72 & 7.74 \\
\hline 2 & 4.85 & 6.97 & 8.28 \\
\hline 3 & 2.72 & 3.43 & 5.15 \\
\hline 4 & 1.91 & 4.11 & 5.60 \\
\hline
\end{tabular}




\begin{tabular}{|l|l|l|l|}
\hline 5 & 2.59 & 3.87 & 5.07 \\
\hline 6 & 1.71 & 3.06 & 3.97 \\
\hline 7 & 3.34 & 4.20 & 5.57 \\
\hline 8 & 1.85 & 3.71 & 5.03 \\
\hline 9 & 3.81 & 5.76 & 6.72 \\
\hline 10 & 2.59 & 3.04 & 3.81 \\
\hline 11 & 2.64 & 4.21 & 5.54 \\
\hline 12 & 5.54 & 6.63 & 7.66 \\
\hline 13 & 4.42 & 5.08 & 6.75 \\
\hline 14 & 3.62 & 4.72 & 5.37 \\
\hline 15 & 4.62 & 7.02 & 7.78 \\
\hline 16 & 5.13 & 6.15 & 7.36 \\
\hline 17 & 2.39 & 4.92 & 6.38 \\
\hline 18 & 2.78 & 3.87 & 6.77 \\
\hline 19 & 3.16 & 3.56 & 5.31 \\
\hline 20 & 3.23 & 3.61 & 4.85 \\
\hline 21 & 2.95 & 3.81 & 5.99 \\
\hline 22 & 4.41 & 5.82 & 7.27 \\
\hline 23 & 2.81 & 3.52 & 4.40 \\
\hline 24 & 3.59 & 6.01 & 8.06 \\
\hline 25 & 3.21 & 5.77 & 7.64 \\
\hline 26 & 2.41 & 4.96 & 6.52 \\
\hline 27 & 3.10 & 4.86 & 6.01 \\
\hline 28 & 2.95 & 4.32 & 5.30 \\
\hline 29 & 2.75 & 3.70 & 6.12 \\
\hline 30 & 2.86 & 4.85 & 7.74 \\
\hline
\end{tabular}

Perbandingan konsumsi energi hasil estimasi denyut jantung dengan total konsumsi energi dapat dilihat pada gambar 4.1. di bawah ini:

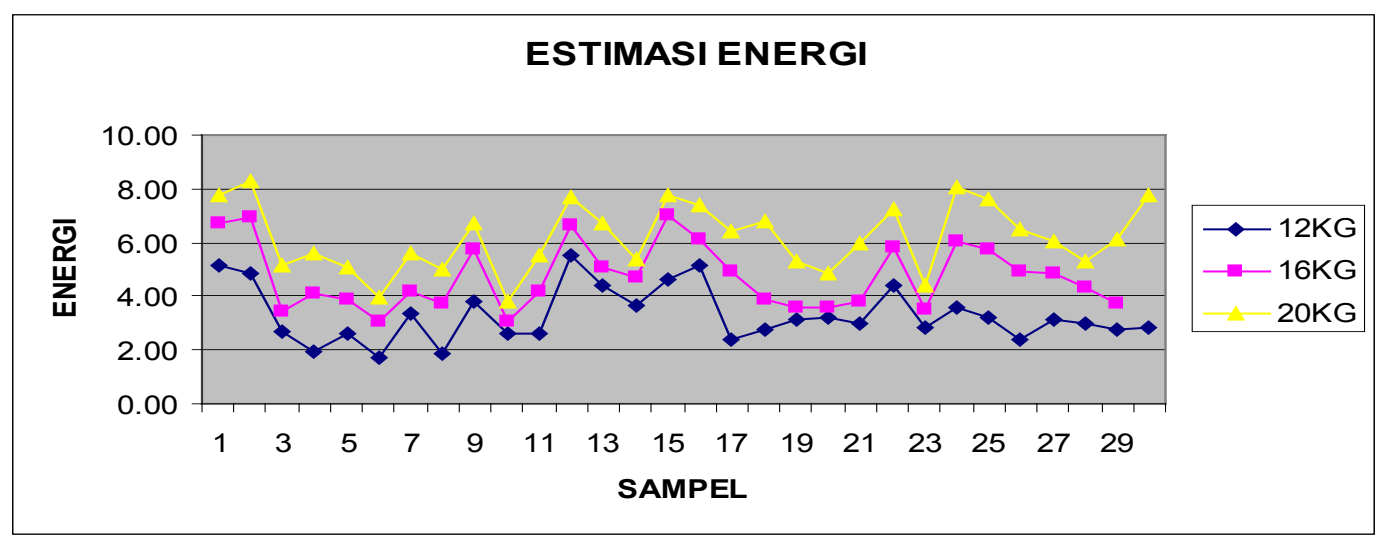

Grafik Perbandingan konsumsi energi hasil estimasi dengan total konsumsi energy 
Uji Normalitas Data Denyut Jantung Beban 12 Kg

One-Sample Kolmogorov-Smirnov Test

\begin{tabular}{|ll|r|r|r|r|}
\hline & & \multicolumn{1}{|c|}{ energi } & \multicolumn{1}{c|}{ umur } & berat badan & tinggi badan \\
\hline $\mathrm{N}$ & & 30 & 30 & 30 & 30 \\
Normal Parameteps' & Mean & 3.3040 & 31.0667 & 66.1667 & 167.3000 \\
& Std. Deviation & 1.0216 & 5.3365 & 10.7321 & 4.6620 \\
Most Extreme & Absolute & .162 & .151 & .143 & .189 \\
Differences & Positive & .162 & .151 & .143 & .189 \\
& Negative & -.094 & -.094 & -.098 & -.078 \\
Kolmogorov-Smirnov Z & .888 & .825 & .785 & 1.036 \\
Asymp. Sig. (2-tailed) & .409 & .504 & .569 & .234 \\
\hline
\end{tabular}

a. Test distribution is Normal.

b. Calculated from data.

Uji Normalitas Untuk Beban 16 Kg

One-Sample Kolmogorov-Smirnov Test

\begin{tabular}{|ll|r|r|r|r|}
\hline & & \multicolumn{1}{c|}{ energi } & \multicolumn{1}{c|}{ umur } & berat badan & tinggi badan \\
\hline $\mathrm{N}$ & & 30 & 30 & 30 & 30 \\
Normal Parameters a,b & Mean & 4.7420 & 31.0667 & 66.1667 & 167.3000 \\
& Std. Deviation & 1.2036 & 5.3365 & 10.7321 & 4.6620 \\
Most Extreme & Absolute & .137 & .151 & .143 & .189 \\
Differences & Positive & .137 & .151 & .143 & .189 \\
& Negative & -.101 & -.094 & -.098 & -.078 \\
Kolmogorov-Smirnov Z & & .753 & .825 & .785 & 1.036 \\
Asymp. Sig. (2-tailed) & & .623 & .504 & .569 & .234 \\
\hline
\end{tabular}

a. Test distribution is Normal.

b. Calculated from data.

Uji Normalitas Untuk Beban 20 Kg

One-Sample Kolmogorov-Smirnov Test

\begin{tabular}{|c|c|c|c|c|c|}
\hline & & energi & umur & berat badan & tinggi badan \\
\hline $\mathrm{N}$ & & 30 & 30 & 30 & 30 \\
\hline \multirow[t]{2}{*}{ Normal Parameters $\quad 8,0$} & Mean & 6.1920 & 31.0687 & 66.1687 & 167.3000 \\
\hline & Std. Deviation & 1.2570 & 5.3365 & 10.7321 & 4.6620 \\
\hline Most Extreme & Absolute & .115 & .151 & .143 & .189 \\
\hline \multirow[t]{2}{*}{ Differences } & Positive & .115 & .151 & .143 & .189 \\
\hline & Negative & -109 & -.094 & -.098 & -.078 \\
\hline Kolmogorov-Smirnov Z & & .627 & .825 & .785 & 1.036 \\
\hline Asymp. Sig. (2-tailed) & & .828 & .504 & .569 & .234 \\
\hline
\end{tabular}
a. Test distribution is Normal.
b. Calculated from data. 
Tabel Hasil Perhitungan Konsumsi Energi Berdasarkan Persamaan Pembebanan Untuk Beban 12 Kg

\begin{tabular}{|c|c|c|c|c|c|c|}
\hline $\mathrm{NO}$ & Umur & $\begin{array}{l}\text { Berat } \\
\text { Badan }\end{array}$ & $\begin{array}{l}\text { Tinggi } \\
\text { Badan }\end{array}$ & $\begin{array}{l}\text { Variabel Energi } \\
\text { Dan Umur } \\
\text { (kilokalori/menit) }\end{array}$ & $\begin{array}{c}\text { Variabel Energi } \\
\text { Dan Berat Badan } \\
\text { (kilokalori/menit) }\end{array}$ & $\begin{array}{l}\text { Variabel Energi } \\
\text { Dan Tinggi } \\
\text { Badan } \\
\text { (kilokalori/menit) }\end{array}$ \\
\hline 1 & 32 & 55 & 167 & & 3.54 & \\
\hline & 38 & 62 & 67 & 3.54 & .39 & \\
\hline 3 & 25 & 58 & 64 & & 3.48 & \\
\hline 4 & 33 & 82 & 75 & & 2.97 & .90 \\
\hline 5 & 27 & 65 & 72 & 7 & 3.33 & 3.06 \\
\hline$\frac{6}{6}$ & 27 & 85 & 72 & 3.17 & 2.91 & 3.06 \\
\hline & 34 & 68 & 65 & 3.40 & 3.27 & \\
\hline 8 & 30 & 78 & 65 & & 3.06 & \\
\hline 9 & 25 & 60 & 64 & 3.10 & 3.43 & \\
\hline 0 & 31 & 59 & 67 & 3.30 & 3.46 & \\
\hline 1 & 26 & 65 & 65 & & 3.33 & \\
\hline 2 & 30 & 65 & 65 & & 3.33 & 3 \\
\hline 3 & $\frac{30}{38}$ & $\frac{\pi}{83}$ & 73 & 3.54 & 2.95 & 3.0 \\
\hline$\frac{4}{4}$ & 23 & 63 & 65 & 3.04 & 3.37 & \\
\hline 5 & 35 & 78 & 64 & 3.44 & 3.06 & \\
\hline 6 & 34 & 70 & 63 & 40 & 3.22 & \\
\hline 7 & 27 & 70 & 63 & 17 & 22 & \\
\hline 8 & 25 & 62 & 79 & 3.1 & 3.39 & \\
\hline$\frac{0}{9}$ & $\frac{2}{27}$ & $\frac{22}{55}$ & 70 & 3.17 & 3.54 & \\
\hline 20 & 36 & 55 & 60 & 3.47 & 3.54 & 3.6 \\
\hline & 42 & 87 & & 3.67 & 2.87 & \\
\hline 22 & 27 & 54 & 65 & 3.17 & 3.56 & 3.42 \\
\hline 23 & 28 & 65 & 60 & 3.20 & 3.33 & 3.68 \\
\hline & 28 & 68 & 71 & 3.20 & & \\
\hline$\frac{7}{25}$ & 26 & 52 & $\frac{11}{62}$ & 3.14 & 3.60 & \\
\hline 26 & 31 & 84 & 70 & 3.30 & 2.93 & \\
\hline 27 & 29 & 64 & 74 & 3.24 & 3.35 & 295 \\
\hline 28 & 40 & 70 & 69 & 3.60 & 3.22 & 3.2 \\
\hline 29 & 37 & 53 & 66 & 3.50 & 3.58 & 3.3 \\
\hline 30 & 41 & 50 & 64 & 3.64 & 3.64 & 3.47 \\
\hline
\end{tabular}

Tabel Hasil Perhitungan Konsumsi Energi Berdasarkan Persamaan Pembebanan Untuk Beban 16 Kg

\begin{tabular}{|c|c|c|c|c|c|c|}
\hline $\mathrm{NO}$ & Umur & $\begin{array}{l}\text { Berat } \\
\text { Badan }\end{array}$ & $\begin{array}{l}\text { Tinggi } \\
\text { Badan }\end{array}$ & $\begin{array}{c}\text { Variabel Energi } \\
\text { Dan Umur } \\
\text { (kilokalori/menit) }\end{array}$ & $\begin{array}{l}\text { Variabel Energi } \\
\text { Dan Berat Badan } \\
\text { (kilokalori/menit) }\end{array}$ & $\begin{array}{c}\text { Variabel Energi } \\
\text { Dan Tinggi } \\
\text { Badan } \\
\text { (kilokalori/menit) }\end{array}$ \\
\hline 1 & 32 & 55 & 167 & 4.76 & 4.85 & 4.77 \\
\hline 2 & 38 & 62 & 167 & 4.90 & 4.78 & 4.77 \\
\hline 3 & 25 & 58 & 164 & 4.60 & 4.82 & 4.92 \\
\hline 4 & 33 & 82 & 175 & 4.79 & 4.59 & 4.36 \\
\hline 5 & 27 & 65 & 172 & 4.65 & 4.75 & 4.51 \\
\hline 6 & 27 & 85 & 172 & 4.65 & 4.57 & 4.51 \\
\hline 7 & 34 & 68 & 165 & 4.81 & 4.73 & 4.87 \\
\hline 8 & 30 & 78 & 165 & 4.72 & 4.63 & 4.87 \\
\hline 9 & 25 & 60 & 164 & 4.60 & 4.80 & 4.92 \\
\hline 10 & 31 & 59 & 167 & 4.74 & 4.81 & 4.77 \\
\hline 11 & 26 & 65 & 165 & 4.63 & 4.75 & 4.87 \\
\hline 12 & 30 & 65 & 165 & 4.72 & 4.75 & 4.87 \\
\hline 13 & 38 & 83 & 173 & 4.90 & 4.59 & 4.46 \\
\hline 14 & 23 & 63 & 165 & 4.56 & 4.77 & 4.87 \\
\hline 15 & 35 & 78 & 164 & 4.83 & 4.63 & 4.92 \\
\hline 16 & 34 & 70 & 163 & 4.81 & 4.71 & 4.97 \\
\hline 17 & 27 & 70 & 163 & 4.65 & 4.71 & 4.97 \\
\hline 18 & 25 & 62 & 179 & 4.60 & 4.78 & 4.16 \\
\hline 19 & 27 & 55 & 170 & 4.65 & 4.85 & 4.62 \\
\hline 20 & 36 & 55 & 160 & 4.86 & 4.85 & 5.12 \\
\hline
\end{tabular}




\begin{tabular}{|r|r|r|r|r|r|r|}
\hline 21 & 42 & 87 & 173 & 4.99 & 4.55 & 4.46 \\
\hline 22 & 27 & 54 & 165 & 4.65 & 4.86 & 4.87 \\
\hline 23 & 28 & 65 & 160 & 4.67 & 4.75 & 5.12 \\
\hline 24 & 28 & 68 & 171 & 4.67 & 4.73 & 4.56 \\
\hline 25 & 26 & 52 & 162 & 4.63 & 4.88 & 5.02 \\
\hline 26 & 31 & 84 & 170 & 4.74 & 4.58 & 4.62 \\
\hline 27 & 29 & 64 & 174 & 4.70 & 4.76 & 4.41 \\
\hline 28 & 40 & 70 & 169 & 4.95 & 4.71 & 4.67 \\
\hline 29 & 37 & 53 & 166 & 4.88 & 4.87 & 4.82 \\
\hline 30 & 41 & 50 & 164 & 4.97 & 4.89 & 4.92 \\
\hline
\end{tabular}

Tabel Hasil Perhitungan Konsumsi Energi Berdasarkan Persamaan Pembebanan Untuk Beban 20 Kg

\begin{tabular}{|c|c|c|c|c|c|c|}
\hline NO & Umur & $\begin{array}{l}\text { Berat } \\
\text { Badan }\end{array}$ & $\begin{array}{l}\text { Tinggi } \\
\text { Badan }\end{array}$ & $\begin{array}{c}\text { Variabel Energi } \\
\text { Dan Umur } \\
\text { (kilokalori/menit) }\end{array}$ & $\begin{array}{c}\text { Variabel Energi } \\
\text { Dan Berat Badan } \\
\text { (kilokalori/menit) }\end{array}$ & $\begin{array}{c}\text { Variabel Energi } \\
\text { Dan Tinggi } \\
\text { Badan } \\
\text { (kilokalori/menit) }\end{array}$ \\
\hline 1 & 32 & 55 & 167 & 6.24 & 6.41 & 6.19 \\
\hline 2 & 38 & 62 & 167 & 6.52 & 6.27 & 6.19 \\
\hline 3 & 25 & 58 & 164 & 5.91 & 6.35 & 6.22 \\
\hline 4 & 33 & 82 & 175 & 6.28 & 5.89 & 6.11 \\
\hline 5 & 27 & 65 & 172 & 6.00 & 6.22 & 6.14 \\
\hline 6 & 27 & 85 & 172 & 6.00 & 5.83 & 6.14 \\
\hline 7 & 34 & 68 & 165 & 6.33 & 6.16 & 6.21 \\
\hline 8 & 30 & 78 & 165 & 6.14 & 5.97 & 6.21 \\
\hline 9 & 25 & 60 & 164 & 5.91 & 6.31 & 6.22 \\
\hline 10 & 31 & 59 & 167 & 6.19 & 6.33 & 6.19 \\
\hline 11 & 26 & 65 & 165 & 5.95 & 6.22 & 6.21 \\
\hline 12 & 30 & 65 & 165 & 6.14 & 6.22 & 6.21 \\
\hline 13 & 38 & 83 & 173 & 6.52 & 5.87 & 6.13 \\
\hline 14 & 23 & 63 & 165 & 5.81 & 6.26 & 6.21 \\
\hline 15 & 35 & 78 & 164 & 6.38 & 5.97 & 6.22 \\
\hline 16 & 34 & 70 & 163 & 6.33 & 6.12 & 6.23 \\
\hline 17 & 27 & 70 & 163 & 6.00 & 6.12 & 6.23 \\
\hline 18 & 25 & 62 & 179 & 5.91 & 6.27 & 6.06 \\
\hline 19 & 27 & 55 & 170 & 6.00 & 6.41 & 6.16 \\
\hline 20 & 36 & 55 & 160 & 6.42 & 6.41 & 6.27 \\
\hline 21 & 42 & 87 & 173 & 6.71 & 5.79 & 6.13 \\
\hline 22 & 27 & 54 & 165 & 6.00 & 6.43 & 6.21 \\
\hline 23 & 28 & 65 & 160 & 6.05 & 6.22 & 6.27 \\
\hline 24 & 28 & 68 & 171 & 6.05 & 6.16 & 6.15 \\
\hline 25 & 26 & 52 & 162 & 5.95 & 6.47 & 6.24 \\
\hline 26 & 31 & 84 & 170 & 6.19 & 5.85 & 6.16 \\
\hline 27 & 29 & 64 & 174 & 6.10 & 6.24 & 6.12 \\
\hline 28 & 40 & 70 & 169 & 6.61 & 6.12 & 6.17 \\
\hline 29 & 37 & 53 & 166 & 6.47 & 6.45 & 6.20 \\
\hline 30 & 41 & 50 & 164 & 6.66 & 6.51 & 6.22 \\
\hline
\end{tabular}




\section{KESIMPULAN}

Dari hasil penelitian diatas maka dapat disimpulkan bahwa:

Berdasarkan hasil perhitungan persamaan pembebanan maka rata-rata energi yang diperlukan untuk pengangkatan beban $12 \mathrm{Kg}, 16 \mathrm{~kg}$, dan $20 \mathrm{Kg}$ adalah $3-6$ kilokalori/menit. Dengan demikian pengangkatan beban pada " $X$ " Fitness Center dengan ukuran $12 \mathrm{~kg}, 16 \mathrm{~kg}$, dan $20 \mathrm{~kg}$ masih diijinkan untuk pengangkatan, karena beban dengan ukuran sekian masih dikategorikan dalam beban kerja ringan dan sedang.

\section{DAFTAR PUSTAKA}

Asnaldi Arie, S.Pd., Pengenalan Macammacam Udara \& Cara Mengukur Denyut Nadi, http://wartawarga.gunadarma.ac.id/ 2010/01/ Wednesday, 04 March 2009.

BPS 2000. Usia Prokduktivitas Kerja Untuk Pekerja Indonesi, http://earning.indonusa.ac id/mod/resource/piu 9 April 2010.

Grandjean, E.Filting the task to the mean. A. Texbook of occupational Ergonomics 4thn ed. London; Taylor and Francis. 1986.

Kurniawan Albert, SE. 2009 Belajar Mudah SPSS. Penerbit Mediakom Yogyakarta

Nurmianto, E. 1996. Ergonomi, Konsep Dasar dan Aplikasinya. P.T. Guna Widya. Jakarta.

P.A. Surjadi 1990. Pendahuluan Teori Kemungkinan Dan Statistika, Edisi 4 Penerbit Institut Teknologi Bandung. Bandung.

P.B Triton. 2004 SPSS 13.0 Terapan Riset Statistika arametrik. Penerbit PT. C.V ANDI OFFSET Yogyakarta.

Santoso Slamet, Analisis Regresi Dan Korelasi http://s.santoso.blogsopt.com 5 April 2010.

Sutalaksana, Iftikar.Z, Anggawisastra Ruhana; Tjakraatmadjaan H, 1979. Teknik Tata Cara Kerja, Laboratorium Tata Cara Kerja Dan Ergonomi. Diterbitkan oleh Departemen Teknik Industri Institut Teknologi Bandung.

Wingjasoebroto Sritomo, 1995 Ergonomi Studi Gerakan Dan Waktu, Teknik Analisis Untuk Peningkatan Produktivitas Kerja, Edisi 1, Penerbit: PT. Gunawidya Jakarta. 